\title{
A Case Study on the Development of Rural E-Commerce through Social Network
}

\author{
Jingjing Zhao, Yunlong Ding*
}

School of Economics and Management, Harbin Institute of Technology, Harbin 150001, P. R. China

Keywords: rural e-commerce; social network; agricultural network company; China;

\begin{abstract}
The 21st Century is the Age of Information when information is the productivity for the development of the market economy. Rural e-commerce as one of the effective ways to solve the Chinese three-dimensional rural issues, has become the consensus of the whole society. In the 2017 No.1 document of the Central Committee of the Communist Party of China, opinions of the State Council on strengthening the efforts to coordinate urban and rural development and further consolidate the foundation of agricultural and rural development, it is clearly pointed out to "promote rural e-commerce, actively support the construction of rural telecommunications and mobile Internet infrastructure, and improve the comprehensive information service system of rural areas." However, due to the lack of understanding of informatization, the huge investment of software and hardware funds and the difficulty of establishing a long-term rural information collection and release system, the whole construction of e-commerce in rural areas is obviously lagged behind the pace of economic development in China, so it is urgent to study a set of rural e-commerce construction solutions under the new situation.
\end{abstract}

\section{The Current Situation of Rural E-Commerce in China}

In recent years, in the favorable atmosphere that the Party and the state attach great importance to the issues relating to agriculture, rural areas, and rural people, the construction of rural e-commerce in China has been carried out steadily and healthily, and the degree of informatization has been greatly improved, which has played an important role in promoting the development of agricultural industrialization and rural economy, mainly reflected in the following aspects: First, the construction of rural e-commerce infrastructure has made a progressive achievement, such as "village to village" project and "household to household" project. Second, a number of information collection and transmission channels covering agriculture and rural economic society have been basically formed, which speeds up the development and utilization of information resources, such as the modern rural information service system of "multi-network integration" mode. Third, the development and application level of information technology in the agricultural field has been greatly improved, such as computer agricultural expert system, portable agricultural information consulting system (Nongwutong), multimedia digital terminal applied to modern rural distance education and training. Fourth, the level of information and technology services for agriculture, rural areas and farmers has been significantly improved. Fifthly, the talent team engaged in agriculture and rural e-commerce construction has been initially trained.

The construction of rural e-commerce in China started late, and its development is relatively backward due to the restriction of region, economy and cognition. Although the construction of rural e-commerce for more than ten years has laid a certain social foundation for building a moderately prosperous society in an all-round way in China, there are still many problems, and the development is not coordinated: the construction of rural distance education service system has been initially applied; rural grassroots e-government, village affairs and business services are rarely known by people; the construction process of data resources in rural society is slow; rural infrastructure construction is weak, and affected by regional economy and regional development imbalance; information resources are not systematic, services are not timely, and the application level is shallow; "digital divide", "last one mile" and other issues are becoming more and more 
prominent, which are seriously constraining the development of rural e-commerce[1].

Among numerous problems of rural e-commerce development, the key of rural e-commerce lies in the imperfection of rural e-commerce system. In the final analysis, rural e-commerce is to solve the urgent needs of the most grassroots farmers for information, without which there will be no significance to talk about rural e-commerce. Among the numerous information media, mobile Internet has become an important means to solve rural e-commerce with its unique advantages. It is the most effective way for farmers to understand external information and release information through mobile Internet[2]. However, at present, only the provincial agricultural administrative departments and $17 \%$ of the prefecture level agricultural administrative departments have set up agricultural information websites, and more than half of the county-level agricultural departments have no agricultural information websites. Of the nearly 40,000 villages and towns in China, only over 17,000 have computers and access to the Internet[3]. In terms of the whole country, there are very few provinces, cities, counties and townships with all the networks connected, and few information stations at the village level. It is not realistic for villagers to get information to query and release at the county level or above information service stations, even at the township level. So it is very necessary to set up information service station in the village, which is also the most effective way to solve the rural e-commerce. That is to say, when the information service station is set up in the village, a village level informant should also be assigned to query and release information for the majority of farmers, and a long-term mechanism should also be established to ensure that the informant actively and fully queries and issues information for farmers.

\section{A Case Study of Rural E-Commerce Construction}

The development of rural e-commerce can not be indulged in empty talk, because farmers are most concerned about how much income to increase. Therefore, the rural e-commerce construction should not only be superficial, and the method of enabling farmers to access external information should be deeply studied to guide their production and life to promote their production and income. A great concern has been given for the construction of rural e-commerce by all sectors of society. In addition, many units are actively carrying out research and practice, among which there is a rural e-commerce construction plan called Heilongjiang Rural Network Information Service Co., Ltd. which is worth reference and research.

\subsection{Case overview}

Heilongjiang Agricultural Network Information Service Co., Ltd. (hereinafter referred to as "Agricultural Network Company") has been committed to the research and practice of rural e-commerce solutions in China, carrying out corresponding information services, and has made a series of important research and practice results. Its practical solution of rural and agricultural informatization has achieved good results in the pilot and practice of 46 counties (there are a total of 68 counties in Heilongjiang Province). Not only the computers are equipped to the villages through the market-oriented operation, but also the large-scale agricultural portal website, including all administrative village websites in Heilongjiang Province, website groups of farmers' professional cooperatives and comprehensive information service network of farmers, has been established, and the information service station has been set up in the village. In addition, a village informant is trained to be responsible for the collection and release of information in the village, and a long-term mechanism is established through the market-oriented operation of social network to enable village informants to obtain corresponding labor remuneration while collecting and releasing information. This set of practical solutions to develop rural e-commerce through social network has achieved significant economic and social benefits, and made some contribution to the construction of rural e-commerce in China.

Rural e-commerce solutions of Agricultural Network Company are as follows: the market-oriented operation enables investors to directly invest in the provision of computers for each administrative village, set up information service stations in the village and train village accountants as village level informants, who are responsible for publicizing, guiding and organizing the 
villagers in their own village to obtain and release all kinds of valuable information they want through the village level information service stations, including agricultural products transaction, second-hand goods, rural land transfer, rural marriage introduction, rural livestock transaction, rural employment and other agricultural information, which can basically meet the needs of farmers for information.

Investors pay attention to return on their investment. The village level informants also need to be paid in their information inquiry, collection and release so that they can voluntarily and actively provide information services for farmers for a long time and a long-effect mechanism can be established. Thus, a model with return on investment is needed, otherwise this scheme will not go on. The key to the success of rural e-commerce is the recovery of investors' funds and the payment of village informants' labor remuneration. Through the in-depth analysis of the rural agricultural material market, the Agricultural Network Company learnt that the price of agricultural products purchased by the farmers is much higher than the factory price of the agricultural producers even if the reasonable transportation and storage costs are added, and this part of the fees that should not be paid by the farmers has been carved up by the agricultural dealers, in which way the farmers suffer huge economic losses every year. In view of this, the Agricultural Network Company directly cooperates with and reaches an agreement with the producers of agricultural products to let the informant be responsible for releasing the information of purchasing agricultural materials directly from the producers for the farmers in the village. In addition, the producers of agricultural products pay for the investment of computers, while the remaining funds are paid to the informant as a reasonable information service fee. After five years of operation practice from 2006 to now, it has been proved by the Agricultural Network Company that in addition to allowing investors to safely recover their investment in computer equipment, the village level information officers have also received information service fees. More importantly, the actual price of agricultural materials purchased by farmers is significantly lower than the market price, achieving a win-win situation.

\subsection{Specific hardware solutions for rural e-commerce construction operated by Agricultural Network Company}

Due to the large number of villages, high value of hardware itself, and the difficulty of full allocation of national finance, the investment of hardware in rural e-commerce has become one of the most difficult aspects of all rural e-commerce problems. Taking Heilongjiang Province as an example, there are nearly 10,000 administrative villages in the whole province. If each administrative village is equipped with a common desktop computer at 3,000 yuan per set, a total of 30 million yuan of huge capital investment is needed, which does not include the investment in software such as website construction. So it is very difficult to solve the problem of rural e-commerce hardware investment without market-oriented operation.

Through the experiment and practice in 46 counties of Heilongjiang Province, Agricultural Network Company has found out a set of hardware investment scheme, the specific scheme is as follows:

First, Agricultural Network Company reaches an agreement with the computer equipment investors to invest in computer equipment.

Second, Agricultural Network Company reaches an agreement with the provincial agricultural economic center, a unit directly under the Heilongjiang Provincial Agricultural Committee, to equip the accountant of the administrative villages under the management center at all levels with computer equipment. At the same time, the village accountant, as the informant of Agricultural Network Company, is responsible for providing the vast number of farmers in the village with mobile Internet information query and information release.

Third, Agricultural Network Company reaches agreements with several well-known producers of agricultural products in China. The village informants are responsible for providing the producers with the information of agricultural products to be purchased by the farmers in the village directly in the form of group purchase. The producers pay the corresponding information fees to the computer investors and the village informants according to the amount of group purchase 
information.

Fourth, the agricultural network company distributes the agricultural materials purchased by the farmers to the village through a special logistics enterprise. At this point, the whole process is completed.

This kind of operation makes the state and individuals free up. The capital comes from the expenses of multi-level distribution of agricultural production products. Most of these expenses are surrendered to farmers, some of which are used to pay for the investment of computer investors, and the rest are paid to village level informants.

\subsection{Specific software solutions for rural e-commerce construction operated by Agricultural Network Company}

First, Agricultural Network Company establishes the agricultural economic information website for each county economic management station to display all kinds of information.

Second, Agricultural Network Company establishes village level websites for all administrative villages to display the general situation of each village, industrial structure, economic development status, main agricultural and sideline products, characteristic agricultural and sideline products, contact information of village economic person, etc.

Third, Agricultural Network Company sets up portal websites and sites for all farmers' professional cooperative to display all kinds of information such as cooperative products, supply and demand, investment promotion, cooperation, etc.

Fourth, Agricultural Network Company establishes a comprehensive agricultural information service website, covering agricultural products trading, second-hand goods trading, rural land circulation, rural livestock trading, rural employment, rural matchmaking service and other information, to provide agricultural information services. According to the actual needs of farmers for various types of information, the website opens up a number of service columns, introduces a large amount of real and valuable agricultural information, and provides one-way information services such as the whole network search engine.

Fifthly, Agricultural Network Company invites agricultural experts to answer all kinds of agricultural problems of farmers online.

Sixthly, Agricultural Network Company appoints village accountants as village level informants who are trained to provide information services for farmers. At the same time, when the computers are put into use, Agricultural Network Company will focus on information service training for the informants of each village covering the basic knowledge, operation methods, network knowledge of computer, information query and information release by the computer, so that they can simply operate the computer, query and release information online in the initial stage, and then operate, query and release information skillfully after practice for half a year.

Seventh, the agricultural information website provides the information interactive platform for the majority of farmers, which reserves the interface for village informant to collect and release information. Farmers can release all kinds of agricultural information to the mobile Internet with the help of the village informant.

\subsection{Benefits brought to farmers by rural e-commerce operated by Agricultural Network Company}

First, the village informants help the farmers to purchase agricultural materials in the form of group purchase, which reduces the expenditure of major agricultural materials such as chemical fertilizer and pesticide, and promotes the income increase of farmers. At the same time, the quality of the agricultural products purchased in group is guaranteed because they are all purchased from formal large factories, which avoids farmers being cheated in purchasing agricultural materials. For example, Agricultural Network Company reached an agreement in 2009 with Sinofert, the largest chemical fertilizer enterprise in China where all the chemical fertilizers for the villagers were purchased by the informant in group. Through the cooperation with Sinofert, not only the quality of chemical fertilizer was guaranteed, but also the price was greatly reduced due to the direct delivery from the manufacturer and the removal of layers of dealers. In 2009, the informants purchased 
about 30,000 tons of chemical fertilizer in groups, and the average price was lower than that of similar products in the market by 100 yuan to 300 yuan per ton. For example, the price of $45 \%$ potassium chloride compound fertilizer was 2,580 yuan per ton, but the lowest price in the market was 2,750 yuan to 2,850 yuan. The group purchase of chemical fertilizer alone saved farmers between 2 million yuan and 3 million yuan, benefiting 36,000 farmers radiated by 1,800 informants.

Second, the village information service stations make it very convenient and timely for farmers to query agricultural market price information, agricultural science and technology information, agricultural policies and regulations information, enrichment information and other agricultural related information. After obtaining the effective information, the majority of farmers use them to guide their production and life, to improve their quality, and promote the production and income.

Third, the channels of farmers' information release have been widened, which has promoted the sales of agricultural and sideline products, the circulation of rural second-hand goods and the circulation of land. According to the research of rural network company, the most urgent information to be released in rural areas mainly includes agricultural product sales, rural second-hand goods, rural land circulation, rural livestock transaction, rural employment, and rural matchmaking. Before the information station was set up in the village in the past, it was very difficult to release such information. Some of them relied on the publicity of relatives and friends, some of them posted advertisements in the village, and so on, which had great limitations and could not achieve the expected results. After the village level information station was set up, the majority of farmers can release information on the mobile Internet with the help of the informant. Once the information is sent, the coverage area expands rapidly, and the information is spread fast. In the past, only some people in the village could know the information after it was released, but after it was released through the mobile Internet, the whole county or even a dozen counties would quickly learn the information, greatly improving the transaction rate of the information. Since Agricultural Network Company launched its website, there have been nearly 30,000 pieces of information published. According to incomplete statistics, the transaction rate has reached more than $60 \%$. There are many second-hand goods information, such as second-hand tractors and combine harvesters, which can be concluded on the same day when they are released, which is enough to show how eager farmers are for information.

Fourth, the information service station has changed the rural life state to a certain extent. First of all, farmers have developed a habit of going to the village information service station for help once there is something they don't understand or want to check, which will improve the quality of farmers themselves and enrich their knowledge in the long run. Second, through Internet video and other tools, many farmers can chat with their relatives in the distance without leaving the village, which greatly facilitates farmers and saves money. In Jiankang Village, Yushu Town of Fujin, a farmer chats with his son's girlfriend in Beijing through online video, which was unimaginable in the past, but now has become true. Third, the villagers are organized to watch online videos on agricultural technology, including planting, breeding, processing industry, which improves the level of agricultural technology and their own quality.

\subsection{Advantages of rural e-commerce solutions operated by Agricultural Network Company}

First, on the premise that the state and individuals do not need to invest in computer equipment, the villages are equipped with computers, and the funds are provided by agricultural material producers, which saves money.

Second, the village information service station has been established, and the village accountant has been trained as the informant. They can get the corresponding service charge while providing the information service for the farmers in the village, which forms a long-term and effective rural e-commerce service mechanism.

Third, the computers are provided to the village accountants directly managed by the economic management stations, and Agricultural Network Company also establishes the website and online office system for the informatization of the economic management stations at all levels. The station itself has the function of serving the farmers, so they are willing to assign the village accountant to 
provide the information service as the informant, and make full use of the complete management system from the organizational system to the village. Only with such a system can the rural e-commerce service be embodied in a real entity, and the rural e-commerce can be implemented smoothly.

Fourth, through the rural e-commerce mode provided by Agricultural Network Company, farmers can not only get good information service without going out of villages, but also effectively save the planting cost through group purchase of agricultural materials with the help of informants, which indirectly increases income.

\section{Conclusion}

In a word, the rural e-commerce can be realized through the full and effective integration of the resources of computer investors, the whole management system, the agricultural material producers and the farmers. In this new situation, the plan of rural e-commerce construction is worthy of consideration and reference by all parties concerned about rural e-commerce.

\section{References}

[1] Zhou Yingping. Discussion on promoting rural informatization construction. Modern Information, 2018, (3): 56-57.

[2] Wang Rong. Analysis of the role of information resources in the construction of new countryside. Library Tribune, 2017, (6): 163-164.

[3] Yue Dabo, Liu Quan, Yan Zhengchun. Discussion on promoting the construction of new rural informatization in China. Office Automation, 2018, (4): 16-18. 